\title{
Larval development of the Pacific sandperch (Prolatilus jugularis) (Pisces: Pinguipedidae) from the Independencia Bight, Pisco, Peru
}

\author{
Jose A. Vélez** ${ }^{\ddagger}$, William Watson ${ }^{\dagger}$, Elaine M. Sandknop ${ }^{\dagger}$ and Wolf Arntz* \\ *Alfred Wegener Institute for Polar and Marine Research, Columbusstrasse, D-27568 Bremerhaven, Germany. ${ }^{\dagger}$ National Marine \\ Fisheries Service, Southwest Fisheries Science Center, 8604 La Jolla Shores Drive, CA 92037-1508, USA. ${ }^{\ddagger}$ Corresponding author, \\ e-mail: jvelez@awi-bremerhaven.de
}

\begin{abstract}
Morphological development of larval Prolatilus jugularis from Bahia Independencia, Pisco, Peru is described. Two hundred and thirty-two specimens were collected with plankton nets in 2000; a developmental series of 40 individuals $(2.5-25.9 \mathrm{~mm}$ : recently hatched through transformation) was assembled using morphological features and pigmentation. Prolatilus jugularis hatches at approximately $2.5 \mathrm{~mm}$, notochord flexion begins at $\sim 5.7 \mathrm{~mm}$ and ends at $\sim 6.9 \mathrm{~mm}$, and transformation begins at an unknown size between 14.2-20.3 mm (probably near $20 \mathrm{~mm}$ ). Diagnostic features of the larvae include a robust body with large head bearing small preopercular spines that begin to form by late preflexion stage; preanal length just under half of body length early in the preflexion stage increasing to near two-thirds of body length in the postflexion stage; and pigmentation primarily on the snout, opercular region, dorsally on the head and gut, laterally above the hindgut, and on the ventral margin of the tail through early flexion stage. A broad mid-lateral stripe begins to form on the trunk and tail late in the flexion stage and dorsal pigmentation forms on the trunk and tail in the postflexion stage. Pectoral-fin rays are first to begin forming, in midpreflexion stage, followed by principal caudal-fin rays, then by pelvic-, dorsal- and anal-fin rays which apparently begin to form simultaneously near the end of preflexion stage. The dorsal fin is long and continuous, with III - IV short spines and 27-29 soft rays, the anal fin contains 21-23 rays, the first one or two of which may be spine-like, the pelvic fins, with I spine, 5 rays, are below or slightly in front of the pectorals (18-20 rays), and there are $9+8$ principal caudal-fin rays and 36-37 myomeres.
\end{abstract}

\section{INTRODUCTION}

After more than a century of research the general knowledge of ichthyoplankton and its ecology remains limited in some regions of the world's oceans (e.g. Richards, 1985; Kendall et al., 1994); this is especially true for South America. Marine fish diversity is high in Peruvian waters, but the larval stages are poorly known; generally, all the scientific work related to Peruvian ichthyoplankton is limited to species of commercial value.

The family Pinguipedidae, originally described by Günther (1860), has been subject of discussion because its monophyly has not been clearly established and the relationships among its genera are uncertain. Several nominal genera have been included in the family and its generic composition is still uncertain, especially in relation to South American forms (see Rosa \& Rosa, 1987, 1997). Pinguipedidae currently is thought to be represented in South America by three endemic genera (Pinguipes, Prolatilus and Pseudopercis) and a single species of Parapercis. Pinguipes includes two species, one distributed from Rio de Janeiro, Brazil to Argentina (Pinguipes brasilianus), the other along the coast of Peru and Chile (P. chilensis); the genus Prolatilus includes only one species: Prolatilus jugularis which occurs on the coast of Peru and Chile; Pseudopercis includes two species, one restricted to southern Brazil (Pseudopercis numida), and the other found from Rio de Janeiro, Brazil, to Argentina (P. semifasciata). Parapersis dockinski is only known from the Juan Fernández Islands, Chile (Rosa \& Rosa, 1997).

Prolatilus jugularis (Valenciennes, 1833) is a marine fish, endemic to the south-east Pacific along the coast of South America from Huacho, Peru $\left(11^{\circ} 11^{\prime} \mathrm{S}\right)$ to Chicloe, Chile $\left(43^{\circ} 43^{\prime} \mathrm{S} 72^{\circ} 50^{\prime} \mathrm{W}\right)$. The species reaches $\sim 40 \mathrm{~cm}$ in length, inhabits rocky and sandy bottoms and feeds on crustaceans, polychaetes and small fish. It is considered a good quality fish and is commercially exploited (Mann, 1954, cited in Rosa \& Rosa, 1997).

Based on rearing of artificially fertilized eggs as well as live eggs collected from the plankton, Fischer (1958) proposed five egg developmental phases for $P$. jugularis and described larval growth from hatching to $4.2 \mathrm{~mm}$. Here we complete the larval description based on our more complete series $(2.5-25.9 \mathrm{~mm})$ and larger number (232) of specimens. A description of development from just after hatching through transformation, including new information about morphology and pigmentation is provided. This description will facilitate identification of the species in ichthyoplankton samples.

\section{MATERIALS AND METHODS}

A developmental series of 40 Prolatilus jugularis, 2.5$25.9 \mathrm{~mm}$, was examined. Larvae were collected during eight months in 2000 in the Independencia Bight, Peru. 


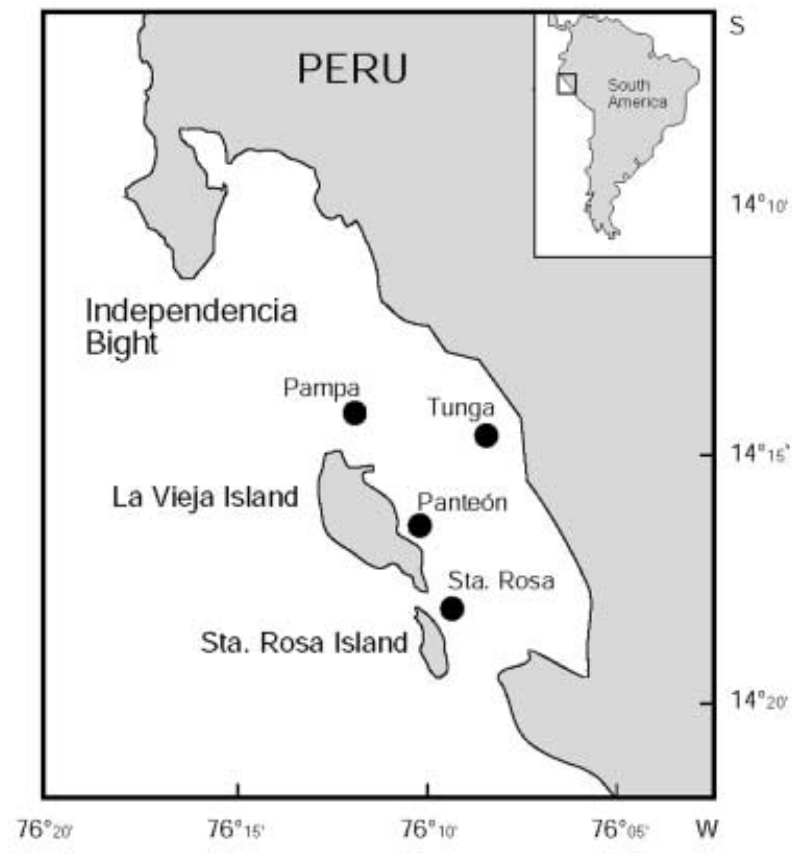

Figure 1. Study area, Independencia Bight, Pisco, Peru. Sampling locations indicated by black points.

Fifty-six horizontal tows were made with a $60-\mathrm{cm}$, nonclosing bongo net $(0.333-\mathrm{mm}$ and $0.505-\mathrm{mm}$ nitex mesh) towed at $10 \mathrm{~m}$ depth, and with a half-metre ring net (0.333-mm mesh), towed at the surface; both nets were equipped with calibrated flowmeters. All tows were taken at speeds of $3 \mathrm{kn}$ for $10 \mathrm{~min}$ and samples were preserved in $4 \%$ formalin solution immediately after collection at each depth at four stations (Figure 1).

In the laboratory all fish larvae were sorted from the samples, identified to the lowest taxon possible, and stored in $4 \%$ formalin. A total of 232 larval $P$. jugularis (2.5$25.9 \mathrm{~mm}$ body length) was identified, and 40 were selected for description. Three larvae $(15.2-25.9 \mathrm{~mm}$, USNM 176428 ) and four adults (91.2 to $146.0 \mathrm{~mm}$, USNM 176428 , 211417) were obtained from the Smithsonian Institution, the National Museum of Natural History; these specimens originally were collected from Chile and Peru.

Larvae were identified by the series method (e.g. Leis \& Carson-Ewart, 2000). The series was united on the basis of consistent morphological characters and pigment patterns throughout.

Only specimens in good condition were used and measured (nearest $0.02 \mathrm{~mm}$ ) with the ocular micrometer of a dissecting microscope within 18 months after collection. Methods of counting and landmarks for measurements are defined by Moser (1996) and Leis \& Carson-Ewart (2000). Body parts measured were: body length (BL), snout-anus length (Sn-A), body depth (BD), head length (HL), head width (HW), snout length (SnL), eye diameter (ED), pectoral fin length $\left(\mathrm{P}_{1} \mathrm{~L}\right)$ and pelvic fin length $\left(\mathrm{P}_{2} \mathrm{~L}\right)$. Larval lengths in the following description always refer to BL. Most larvae were lightly stained with alizarin red-S to aid in counting fin rays and in determining the sequence of fin formation. Seven specimens ranging from transformation to adult were selected for radiography in order to obtain more accurate meristic counts. The morphometric series also served as the basis for descriptions of the pigment pattern. Descriptions of pigmentation refer solely to melanistic pigment. Six specimens were illustrated to show pigmentation characters and morphological changes, and to provide identification of all post-hatching developmental stages of P. jugularis.

\section{RESULTS}

\section{Distribution and abundance}

There are no published data on the distribution of larval Prolatilus jugularis. In our surveys $P$. jugularis accounted for $1.5 \%$ of the total fish larvae taken in Independencia Bight during 2000. Larval P. jugularis were found at all stations, but were most abundant at Santa Rosa (38.6\%) and Tunga (31.2\%), followed by Panteon (23\%), and Pampa $(7.2 \%)$ (Figure 1). Larvae were found only in the samples collected at $10 \mathrm{~m}$ depth, at temperatures ranging from $13.4^{\circ} \mathrm{C}$ to $17.7^{\circ} \mathrm{C}$. Over $90 \%$ of the larvae occurred at mean temperatures of $13.4-14.2^{\circ} \mathrm{C}$. Recently hatched larvae were caught throughout the year (except in May), but in January, February and March the abundances were low and larvae were found at just one of the four stations. Abundances were highest in spring (SeptemberNovember), with approximately $90.7 \%$ of the larvae taken during October and November. Thus spawning extends from at least spring through summer, probably with peak spawning from September to November.

\section{Morphology}

Prolatilus jugularis hatches at a small size: our smallest larva $(2.5 \mathrm{~mm})$ had a small yolk sac. Notochord flexion begins at $\sim 5.7 \mathrm{~mm}$ and ends at $\sim 6.9 \mathrm{~mm}$, and transformation begins at an unknown size between 14.2-20.3 mm (probably near $20 \mathrm{~mm}$ ). Larval development is a gradual process with no marked changes in body proportions. Larvae are moderately deep-bodied and compressed (juveniles and adults remain compressed but are more elongate). Body depth averages 25\% BL in preflexion larvae, increasing to $27 \%$ and $29 \%$ in flexion and postflexion stages, and decreasing to $21 \%$ and $20 \%$ in transformation stage and adults, respectively. The gut is coiled and compact early; preanal length increases from near half $(47-58 \%)$ to about two-thirds BL (64-67\%) during larval development, decreasing to $55 \%$ in transformation stage and to $47 \%$ in adults (Table 1 ). The head is relatively large, broad, and deeper than the body, with a slight dorsal bulge early in the preflexion stage. Head length averages $31-40 \%$ BL through most of the larval period, $36 \%$ during transformation stage, and decreases to $32 \%$ in adults. Head width increases from $54 \%$ to $66 \% \mathrm{HL}$ in early larvae and decreases to $46 \%$ and $39 \%$ HL in transforming larvae and adults, respectively. Eye diameter in preflexion stage larva is about $32 \% \mathrm{HL}$ but decreases to $29 \%$ in flexion stage, to $26-27 \%$ in postflexion and transformation stages, and to $25 \% \mathrm{HL}$ in adults. Pectoral fin length rapidly increases from $10 \% \mathrm{BL}$ in the preflexion stage to $25 \%$ in the transformation stage. The pelvic fin length increases from $5 \%$ BL late in the preflexion stage to $25 \%$ in transformation stage (Table 1 ). 
Table 1. Morphometric data of Prolatilus jugularis larvae from Independencia Bight, Peru (range and mean in decimal fractions).

\begin{tabular}{|c|c|c|c|c|c|c|c|c|c|c|}
\hline \multirow{2}{*}{$\begin{array}{l}\text { Morphometric } \\
\text { data }\end{array}$} & \multicolumn{2}{|c|}{$\begin{array}{c}\text { Preflexion } \\
(2.5-5.6 \mathrm{~mm})\end{array}$} & \multicolumn{2}{|c|}{$\begin{array}{c}\text { Flexion } \\
(5.7-6.9 \mathrm{~mm})\end{array}$} & \multicolumn{2}{|c|}{$\begin{array}{l}\text { Postflexion } \\
(7.0-10.6 \mathrm{~mm})\end{array}$} & \multicolumn{2}{|c|}{$\begin{array}{l}\text { Transformation } \\
(>10.6-25.9 \mathrm{~mm})\end{array}$} & \multicolumn{2}{|c|}{$\begin{array}{c}\text { Adults } \\
(91.2-146.0 \mathrm{~mm})\end{array}$} \\
\hline & Range & Mean & Range & Mean & Range & Mean & Range & Mean & Range & Mean \\
\hline $\mathrm{Sn}-\mathrm{A} / \mathrm{BL}$ & $0.47-0.58$ & 0.54 & $0.51-0.58$ & 0.55 & $0.64-0.67$ & 0.66 & $0.53-0.59$ & 0.55 & $0.44-0.48$ & 0.47 \\
\hline $\mathrm{BD} / \mathrm{BL}$ & $0.20-0.28$ & 0.25 & $0.24-0.30$ & 0.27 & $0.27-0.30$ & 0.29 & $0.21-0.22$ & 0.21 & $0.18-0.22$ & 0.20 \\
\hline $\mathrm{HL} / \mathrm{BL}$ & $0.21-0.37$ & 0.31 & $0.32-0.42$ & 0.36 & $0.38-0.42$ & 0.40 & $0.33-0.39$ & 0.36 & $0.31-0.34$ & 0.32 \\
\hline $\mathrm{HW} / \mathrm{HL}$ & $0.47-0.58$ & 0.54 & $0.50-0.59$ & 0.55 & $0.64-0.68$ & 0.66 & $0.36-0.53$ & 0.46 & $0.37-0.41$ & 0.39 \\
\hline $\mathrm{SnL} / \mathrm{HL}$ & $0.15-0.36$ & 0.28 & $0.24-0.29$ & 0.27 & $0.20-0.29$ & 0.25 & $0.17-0.22$ & 0.21 & $0.31-0.33$ & 0.31 \\
\hline $\mathrm{ED} / \mathrm{HL}$ & $0.26-0.37$ & 0.32 & $0.26-0.35$ & 0.29 & $0.23-0.30$ & 0.26 & $0.23-0.33$ & 0.27 & $0.23-0.27$ & 0.25 \\
\hline $\mathrm{P}_{1} \mathrm{~L} / \mathrm{BL}$ & $0.03-0.15$ & 0.10 & $0.12-0.18$ & 0.15 & $0.14-0.18$ & 0.16 & $0.23-0.26$ & 0.25 & $0.24-0.25$ & 0.24 \\
\hline $\mathrm{P}_{2} \mathrm{~L} / \mathrm{BL}$ & $0.0-0.036$ & 0.005 & $0.013-0.07$ & 0.032 & $0.20-0.23$ & 0.21 & $0.24-0.28$ & 0.26 & $0.23-0.25$ & 0.24 \\
\hline
\end{tabular}

$\mathrm{BD}$, body depth; BL, body length; ED, eye diameter; HL, head length; HW, head width; $\mathrm{P}_{1} \mathrm{~L}$, pectoral fin length; $\mathrm{P}_{2} \mathrm{~L}$, pelvic fin length; Sn-A, snout-anus length; SnL, snout length.

Relatively well-developed preopercular spination forms during the latter preflexion and flexion stages. This consists of a single row of spines along the posterior preopercular margin, originating as a pair of small spines near the preopercular angle at $\sim 4 \mathrm{~mm}$ and increasing to a maximum of 7-10 spines more or less evenly spaced along nearly the full length of the margin by early flexion stage ( $\sim 6 \mathrm{~mm})$. Small serrations are visible along the margin of the anterior (outer) preopercular shelf in some specimens.

\section{Fin development}

The sequence of initial development is: pectoral; caudal and pelvic; dorsal and anal (Table 2). Pectoral fins lacking rays are present in the smallest specimen $(2.5 \mathrm{~mm})$. The upper 2-9 pectoral-fin rays develop in the preflexion stage by $4.3 \mathrm{~mm}$ and the full adult complement of 20 (1820) rays is present by late preflexion or early flexion stage ( $\sim 5.5-5.9 \mathrm{~mm})$. Addition of rays is ventral. The caudal fin begins forming at about $4.5 \mathrm{~mm}$ when the hypurals first appear. Principal caudal-fin rays begin to form at about $4.7 \mathrm{~mm}$, with the full complement of $9+8$ principal rays present by about $5.7 \mathrm{~mm}$ (flexion stage, Figure 2G). The posterior procurrent caudal-fin rays begin to form late in the flexion stage (Table 2) and are gradually added anteriorly through transformation stage, when the full complement of $14-15+11-13$ rays is present (Table 2). The pelvic fin buds form early in the preflexion stage (by $4.5 \mathrm{~mm}$ ) and

Table 2. Development of fin rays of Prolatilus jugularis from Independencia Bight, Peru. Specimens between dashed lines are undergoing notochord flexion. Transformation begins at an unknown size between 14.2-20.3 mm (probably near $20 \mathrm{~mm}$ ), specimens 91.2-146.0 $\mathrm{mm}$ are adults.

\begin{tabular}{|c|c|c|c|c|c|c|c|}
\hline \multirow[b]{2}{*}{ Length (mm) } & \multirow{2}{*}{$\begin{array}{c}\text { Preopercular } \\
\text { spines }\end{array}$} & \multirow[b]{2}{*}{ Dorsal } & \multirow[b]{2}{*}{ Anal } & \multicolumn{2}{|c|}{ Caudal } & \multirow[b]{2}{*}{ Pectoral } & \multirow[b]{2}{*}{ Pelvic } \\
\hline & & & & Principal & Procurrent & & \\
\hline $2.5-3.5$ & $1-2$ & - & - & - & - & - & - \\
\hline 4.3 & 3 & - & - & - & - & 9 & - \\
\hline 4.5 & 3 & - & - & Hypural form & - & 8 & Bud \\
\hline 4.7 & 3 & - & - & $1+1$ & - & 8 & Bud \\
\hline 4.8 & $3-4$ & - & - & $2+2$ & - & Damaged & Bud \\
\hline 5.0 & 5 & Anlage & Anlage & $3+2$ & - & 13 & Bud \\
\hline 5.4 & 6 & Anlage & Anlage & $5+5$ & - & 16 & Bud \\
\hline 5.5 & $6-7$ & Anlage & Anlage & $5+5$ & - & 18 & Bud \\
\hline 5.6 & 7 & $\mathrm{III}+19$ & 22 & $7+6$ & - & 18 & 4 \\
\hline 5.7 & 8 & $\mathrm{III}+19$ & 20 & $9+8$ & - & 18 & 3 \\
\hline 5.9 & $8-9$ & $\mathrm{III}+25$ & 22 & $9+8$ & - & 20 & $\mathrm{I}, 5$ \\
\hline 6.1 & 9 & $\mathrm{III}+21$ & 21 & $9+8$ & - & 20 & $\mathrm{I}, 5$ \\
\hline 6.2 & 9 & III +26 & 21 & $9+8$ & - & 20 & $\mathrm{I}, 5$ \\
\hline $6.3-6.5$ & 9 & $\mathrm{III}+28$ & 21 & $9+8$ & - & 19 & $\mathrm{I}, 5$ \\
\hline 6.6 & $9-10$ & $\mathrm{III}+27$ & 21 & $9+8$ & - & 19 & $\mathrm{I}, 5$ \\
\hline 6.9 & 10 & $\mathrm{III}+28$ & 21 & $9+8$ & $1+1$ & 20 & $\mathrm{I}, 5$ \\
\hline 8.4 & 11 & $\mathrm{III}+29$ & 21 & $9+8$ & $3+2$ & 18 & $\mathrm{I}, 5$ \\
\hline 10.6 & $11-12$ & III +29 & 23 & $9+8$ & $5+4$ & 20 & $\mathrm{I}, 5$ \\
\hline 15.2 & 11 & $\mathrm{III}+29$ & 23 & $9+8$ & $6+5$ & 20 & $\mathrm{I}, 5$ \\
\hline 20.3 & 13 & $\mathrm{III}+28$ & 22 & $9+8$ & $12+9$ & 20 & $\mathrm{I}, 5$ \\
\hline 22.5 & 12 & $\mathrm{IV}+28$ & 22 & $9+8$ & $12+10$ & 20 & $\mathrm{I}, 5$ \\
\hline 25.9 & 16 & IV + 28 & 23 & $9+8$ & $14+12$ & 20 & $\mathrm{I}, 5$ \\
\hline $91.2-146.0$ & $13-16$ & III-IV + 28 & $22-23$ & $9+8$ & $14-15+11-13$ & 20 & I5 \\
\hline
\end{tabular}


A

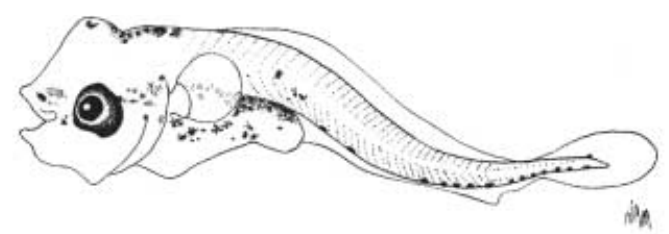

B

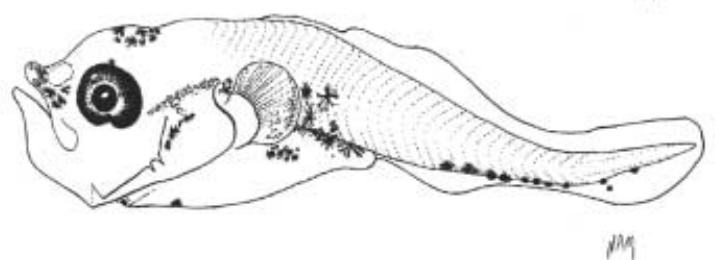

C

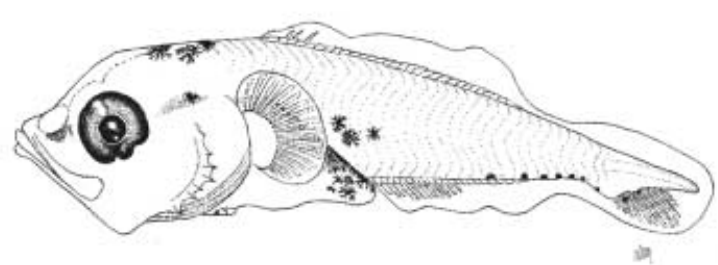

D

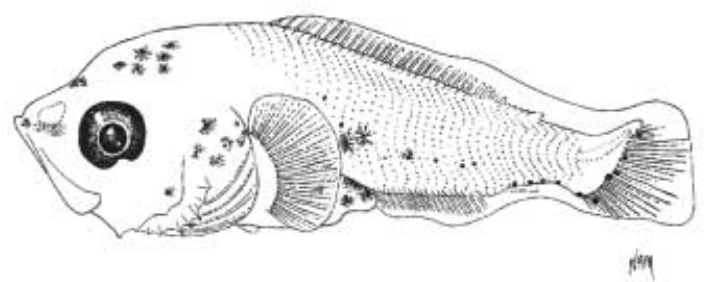

E
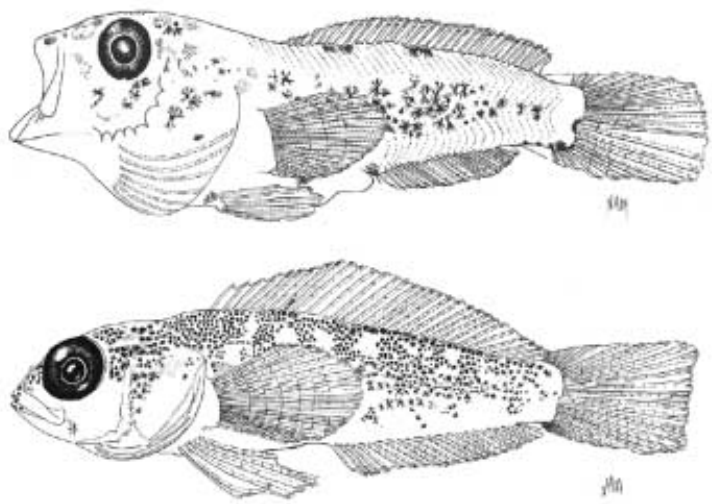

Figure 2. Larvae of Prolatilus jugularis. (A) $2.8 \mathrm{~mm}$ (early preflexion); (B) $4.3 \mathrm{~mm}$ (mid-preflexion); (C) $6.2 \mathrm{~mm}$ (latepreflexion); (D) $6.5 \mathrm{~mm}$ (mid-flexion); (E) $10.6 \mathrm{~mm}$ (late postflexion); (F) $20.3 \mathrm{~mm}$ (transforming). Specimens C and D were slightly less developed than others of similar size.

the full complement of 1 spine and 5 rays is present in the flexion stage by $5.9 \mathrm{~mm}$ (Table 2). The dorsal and anal fins begin to develop simultaneously late in the preflexion stage: the anlage of each is first visible by $\sim 5.0 \mathrm{~mm}$, and by mid-flexion stage $(6.3-6.5 \mathrm{~mm})$ the full complement of III-IV + 27-29 dorsal-fin rays is present (Table 2). Full complements may be present as early as $6.3-6.5 \mathrm{~mm}$ and $5.9 \mathrm{~mm}$, but clearly are not present yet in either fin in the 6.2 and $6.5 \mathrm{~mm}$ specimens illustrated in Figure 2.

\section{Pigmentation}

Melanophores are restricted to the head, gut, trunk and ventral margin of the tail through most of larval development (Figure 2).
Table 3. Summary of some characters in larval Prolatilus jugularis emphasizing progress made in this study since that of Fischer (1958).

\begin{tabular}{|c|c|c|}
\hline Character & This study & Fischer (1958) \\
\hline Collection location & $\begin{array}{l}\text { Independencia } \\
\text { Bight, Peru }\end{array}$ & Valparaiso, Chile \\
\hline $\begin{array}{l}\text { Number of specimens } \\
\text { collected }\end{array}$ & 232 & Not specified \\
\hline $\begin{array}{l}\text { Number of specimens } \\
\text { examined }\end{array}$ & 40 & Not specified \\
\hline Size range $(\mathrm{mm})$ & $2.5-25.9$ & Eggs to 4.2 \\
\hline Total myomeres & $36-37$ & - \\
\hline $\begin{array}{l}\text { Fin developmental } \\
\text { sequence }\end{array}$ & $\begin{array}{c}\text { 1P, Caudal, 2P, } \\
\text { D and A }\end{array}$ & - \\
\hline \multicolumn{3}{|c|}{ Approximate size (mm) at: } \\
\hline Hatching & $<2.5$ & $\begin{array}{l}1.9(2.4-3.1 \\
\text { reared larva) }\end{array}$ \\
\hline Preflexion & $2.5-5.6$ & - \\
\hline Flexion & $5.7-6.9$ & - \\
\hline Postflexion & $>6.9-10.6$ & - \\
\hline Transformation & $>10.6-25.9$ & - \\
\hline $\begin{array}{l}\text { Beginning of hypural } \\
\text { formation }\end{array}$ & 4.5 & - \\
\hline \multicolumn{3}{|c|}{ First appearance of fin anlage } \\
\hline Dorsal & 5.0 & - \\
\hline Anal & 5.0 & - \\
\hline Pelvic & 4.5 (Bud) & - \\
\hline \multicolumn{3}{|c|}{ First appearance of fin-rays } \\
\hline Pectoral & $>3.5<4.3$ & 3.9 \\
\hline Dorsal & 5.6 & - \\
\hline Anal & 5.6 & - \\
\hline Principal caudal rays & 4.7 & - \\
\hline Procurrent caudal rays & 6.9 & - \\
\hline Pelvic & 5.6 & - \\
\hline \multicolumn{3}{|l|}{ Completion of fin-rays } \\
\hline Pectoral & 5.9 & - \\
\hline Dorsal & $6.3-6.5$ & - \\
\hline Anal & $5.6-10.6$ & - \\
\hline Principal caudal rays & 5.7 & - \\
\hline Procurrent caudal rays & $>22.5$ & - \\
\hline Pelvic & $>6.5$ & - \\
\hline \multicolumn{3}{|c|}{ Position of fins (myomere) } \\
\hline Dorsal & $3 \mathrm{rd}-33 \mathrm{rd}$ & - \\
\hline Anal & $12 \mathrm{th}-31 \mathrm{st}$ & - \\
\hline \multicolumn{3}{|l|}{ Total number of fin-rays } \\
\hline Pectoral & 20 & - \\
\hline Dorsal & III-IV + 28 & - \\
\hline Anal & $22-23$ & - \\
\hline Principal caudal & $9+8$ & - \\
\hline Procurrent caudal & $14-15+11-13$ & - \\
\hline Pelvic & $\mathrm{I}, 5$ & - \\
\hline
\end{tabular}

A, anal; C, caudal; D, dorsal; 1P, pectoral; 2P, pelvic.

\section{Head region}

Head pigment always is present. Our smallest larva $(2.5 \mathrm{~mm})$ had eight stellate melanophores scattered dorsally above the brain, scattered melanophores (external and internal) laterally on the head, and on the upper jaw and snout. In that specimen the eyes were becoming pigmented. By $2.8 \mathrm{~mm}$ the dorsal pigment on the head increases (11 melanophores), the eyes are fully pigmented, and the pigment on the snout and upper jaw increase noticeably (Figure 2A). 
In the remaining preflexion stage and flexion stage uniform pigmentation gradually develops over the midbrain region, with 11-24 (usually 11-13) darker melanophores scattered on top (by $6.9 \mathrm{~mm}$ ). At the same time pigmentation spreads anteriorly over the forebrain and posteriorly onto the nape and anterior few myomeres: for example a $4.7 \mathrm{~mm}$ specimen had 2 melanophores on the nape and 3 on the trunk, while 5.4 and $5.6 \mathrm{~mm}$ specimens had 3 and 2 at the nape and 5 and 2 on the trunk, respectively. Melanophores at the nape usually are internal. Some dorsal melanophores on the head begin to extend internally during mid-preflexion stage $(>4.7 \mathrm{~mm})$; there usually are 1-4 internal melanophores. Both internal and external pigment is present laterally on the head throughout larval development (Figure 2). In 2.5$10.6 \mathrm{~mm}$ specimens, this pigment is posterior to the eye and extends from the level of the midbrain to just anterior to the pectoral fin; there are 1-8 external melanophores during the preflexion stage, increasing noticeably during notochord flexion. There are 1-2 melanophores on the interior and exterior surfaces of each nasal capsule throughout development. In specimens up to $6.2 \mathrm{~mm}, 2-6$ melanophores (internal and external) were observed between the eyes. Pigment increases dorsally and dorsolaterally on the head, so that by transformation stage $(\sim 20.3 \mathrm{~mm})$ the upper half of the head is heavily pigmented while the lower half remains very lightly pigmented (Figure $2 \mathrm{~F}$ ).

There are 1-2 and 5-12 melanophores on the interior and exterior surfaces of the upper jaw, respectively; in postflexion specimens these are on the central part of the jaw (Figure 2E). The lower jaw is unpigmented before transformation (Figure 2F). One to three (usually 1) ventral melanophores are found in the gular region through postflexion stage, but disappear at transformation.

\section{Gut, trunk and tail regions}

The gut is always pigmented dorsally and anteriorly, with densest pigmentation internally over the dorsal and dorsolateral surfaces of the swim bladder and nearly the full length of the gut. During the preflexion stage $(\sim 2.5-$ $5.6 \mathrm{~mm}$, Figure 2A,B) there are many internal and external melanophores (19-31, usually 19-22), primarily internally. Pigment spreads downward over the dorsolateral surfaces of the swimbladder and hindgut during the flexion stage ( $\sim 5.7-6.9 \mathrm{~mm}$, Figure $2 \mathrm{~B}, \mathrm{C})$, extending to near the anus posteriorly. At the end of the flexion stage and during the postflexion stage $(\sim 7.0-10.6 \mathrm{~mm}$, Figure $2 \mathrm{E})$ the internal pigment becomes increasingly difficult to see through the thickening abdominal wall.

Ventral pigmentation is absent on the gut through $3.5 \mathrm{~mm}$; from $3.6 \mathrm{~mm}$ onward there are $1-5$ external melanophores along the ventral margin of the hindgut (usually $1-2$ in the preflexion stage; $3-5$ in the postflexion stage). The ventral hingut pigmentation is absent in transforming specimens.

External pigment develops dorsally and laterally on the trunk and tail, and on the ventral margin of the tail. The dorsal pigment first forms anteriorly: preflexion- and flexion-stage specimens have 1-6 (usually 1-3) internal melanophores after the nape; during the postflexion stage (Figure 2E) the pigment on this area increases, forming a band with the opercular melanophores.
The lateral surface of the trunk is always pigmented, primarily on the area above the hindgut in larvae smaller than $\sim 6.2 \mathrm{~mm}$ (preflexion through mid-flexion, Figure $2 \mathrm{~A}-\mathrm{G}$ ); the number of melanophores here increases with larval growth. In specimens larger than $5.4 \mathrm{~mm}$ a group of 3-12 melanophores (usually $3-7$ ) in the hindgut area extends from the trunk over the upper side of the gut. Late in the flexion stage $(6.6-6.9 \mathrm{~mm}) 12-14$ melanophores begin to form a lateral band on the trunk and tail; this pigmentation increases noticeably ( $>26$ melanophores during the postflexion stage), forming a broad midlateral stripe (Figure 2E). During the transformation stage, nine pigment saddles form and extend ventral to, or just below, the lateral line (Figure 2F). Some pigment patches between the saddles also extend to just below the lateral line.

A single row of melanophores is always present along the ventral midline of the tail from postanal myomere 4-6 nearly to the end of the notochord. The number of melanophores in this series decreases during development, from 8-19 (usually 11-14) early in the preflexion stage to only the posterior $4-5$ late in the postflexion stage (Figure $2 \mathrm{~A}-\mathrm{E}$ ); there are $0-1$ (usually none), on the caudal peduncle when present, in transforming specimens (Figure 2F). It is possible that some of the anterior melanophores in the ventral series migrate upward toward the lateral line. The ventral melanophores on the notochord tip become situated at the bases of some of the principal caudal-fin rays (Figure $2 \mathrm{G}-\mathrm{E}$ ); in transforming specimens pigment increases noticeably on the bases of the principal rays, with sparser pigment extending distally. During the preflexion stage 1-3 melanophores can be found on the caudal finfold near the body margin (Figure 2B). These subsequently become located at or near the base(s) of one or more of the lower caudal-fin rays. Early preflexion specimens have a melanophore dorsally on the notochord tip (Figure 2A), which disappears or becomes internal during the preflexion stage.

\section{DISCUSSION}

Fischer (1958), described larval Prolatilus jugularis from hatching to $4.2 \mathrm{~mm}$. In our study, complete larval development from recently hatched larvae through transformation is described and illustrated for the first time. In Table 3 we compare some of the results of our study with those of Fischer (1958). The few results that can be compared between the two studies generally are concordant.

\section{Identification}

Larval Prolatilus jugularis hatch at about 2-3 mm, notochord flexion begins at $\sim 5.7$ and ends at $\sim 6.9 \mathrm{~mm}$, and transformation begins at an unknown size between 14.2$20.3 \mathrm{~mm}$ (probably near $20 \mathrm{~mm}$ ). The most important diagnostic features of the larvae include a robust body with large head bearing small preopercular spines that begin to form by late preflexion stage; preanal length just under half of body length early in the preflexion stage increasing to near two-thirds of body length early in the postflexion stage; and pigmentation primarily on the snout, opercular region, dorsally on the head and gut, laterally above the hindgut, and on the ventral margin of 
the tail through early flexion stage. A broad mid-lateral stripe begins to form on the trunk and tail late in the flexion stage and dorsal pigmentation forms on the trunk and tail in the postflexion stage. Pectoral-fin rays are first to begin forming, in mid-preflexion stage, followed by principal caudal-fin rays, then by dorsal-, anal-, and pelvic-fin rays which apparently begin to form simultaneously near the end of preflexion stage. Pelvic fins are below or slightly in front of the pectorals, the dorsal fin is long and continuous, with III-IV short spines and 27-29 soft rays, the anal fin is long, with 21-23 rays, first one or two of which may be spine-like, there are I,5 pelvic-fin rays, $9+8$ principal caudal-fin rays and 36-37 myomeres.

The early larvae of $P$. jugularis might be difficult to distinguish from those of some other families as their general morphology is similar to that of a number of larvae with relatively large, rounded heads and a row of melanophores midventrally on the tail. This includes some scombrids, nemipterids, sparids, microcanthids, blenniids, nomeids and some myctophids. The nemipterids, sparids, and microcanthids have fewer myomeres than P. jugularis (22-24, 24, and 25 myomeres respectively, vs 36-37). Most nomeids have 30-31 or 40 myomeres; the two eastern Pacific species (both Psenes) that have myomere counts similar to Prolatilus jugularis have preanal length $<50 \%$ BL during the preflexion stage, lack preopercular spines, and have moderately large pelvic fins that form early, far sooner than pelvic fins form in $P$. jugularis. Larvae of the other families commonly have myomere counts in the mid- to high 30 s. The blenniids typically have a shorter preanal length than $P$. jugularis (usually $\approx 40 \%$ BL except $\approx 50 \%$ in many Salariinae, vs usually $\geqslant 50 \%$ in $P$. jugularis) and commonly have enlarged and/or pigmented pectoral fins, may develop much larger preopercular spines than $P$. jugularis, and may develop relatively large recurved teeth. Preflexion stage larvae of most scombrid species also usually have preanal length $<50 \%$ BL $(\approx 50 \%$ in Euthynnus, $>60 \%$ in Acanthocybium), and all have a larger mouth, larger preopercular spines (except scomber), larger teeth, and develop a longer snout compared with P. jugularis. Myctophids generally have an uncoiled, striated gut, most lack preopercular spines, and they commonly are more lightly pigmented than P.jugularis.
This study was supported by the German Academic Exchange Service (DAAD), the Alfred Wegener Institute for Polar and Marine Research (AWI) in Bremerhaven, Germany and the Volkswagen Foundation. The first author thanks Professor Dr M. Wolff, and Dr S. Schiel, for their advice and their support. This study could not have been accomplished without the generous cooperation of many people, particularly Professor Dr Jaime Mendo and his group of students for their assistance in the sampling operations in Peru. I am indebted to the ichthyoplankton groups of IMARPE, Peru; CICIMAR, Mexico and the SWFSC, La Jolla, California for giving me support and providing me space and equipment in their laboratories. I also thank S. Jewett (Smithsonian Institution) who provided specimens, N. Arthur McGehee who executed Figure 2. Special thanks go to H. Prieto, R. Jordan and Dr E. Brinton for their hospitality in San Diego (GA).

\section{REFERENGES}

Fischer, K.W., 1958. Primeras fases del desarrollo del Blanquillo (Prolatilus jugularis) Cuv. Et. Val. (Pisces). Revista de Biología Marina. Publicado por la Estación de Biología Marina de la Universidad de Chile, 3, nos. 1, 2 \& 3, 3-27.

Günther, A., 1860. Catalogue of fishes of the British Museum. London: Trustees of the British Museum, Part II.

Kendall, A.W. \& Matarese, A.C., 1994. Status of early life history descriptions of marine teleosts. Fishery Bulletin, 92, 725-736.

Leis, J.M. \& Carson-Ewart, B.M., 2000. The larvae of Indopacific coastal fishes: an identification guide to marine fish larvae. Fauna Malesiana handbook, no. 2. Leiden: Brill.

Moser, H.G., 1996. The early stages of fishes in the California Current region. In California Cooperative Oceanic Fisheries Investigations Atlas no. 33 (ed. H.G. Moser), pp. 1-1503. Lawrence: Allen-Press, Inc.

Richards, W.J., 1985. Status of the identification of the early life stages of fishes. Bulletin of Marine Science, 37, 756-760.

Rosa, I.L. \& Rosa, R.S., 1987. Pinguipes Cuvier and Valenciennes and Pinguipedidae Günther, the valid names for the fish taxa usually known as Mugiloides and Mugiloididae. Copeia, 4, 1048-1051.

Rosa, I.L. \& Rosa, R.S., 1997. Systematic revision of the South American species of Pinguipedidae (Teleostei, Trachinoidei). Revista Brasileira de Zoologia, 14, 845-865.

Submitted 16 fanuary 2003. Accepted 29 Fuly 2003. 